\title{
MENINGKATKAN HASIL BELAJAR MATEMATIKA MELALUI PENERAPAN MODEL PEMBELAJARAN KOOPERATIF TIPE TGT (TEAMS GAMES TOURNAMENTS) PADA SISWA KELAS V SDN PATRAKOMALA KOTA BANDUNG
}

\author{
Eutik Mulyati dan Guntarsih \\ mulyatieutk22@gmail.com
}

\begin{abstract}
ABSTRAK
Penelitian ini bertujuan untuk meningkatkan hasil belajar siswa kelas V SD Negeri Patrakomala pada mata pelajaran Matematika dengan pokok bahasan operasi hitung bilangan bulat, Kelipatan Persekutuan Terkecil (KPK) dan Faktor Persekutuan Tersebar dengan menggunakan Model Pembelajaran Kooperatif tipe TGT. Penelitian ini merupakan penelitian tindakan kelas kolaboratif. Subjek dalam penelitian ini siswa kelas V SDN Patrakomala dengan jumlah 18 orang siswa. Penelitian ini berlangsung dalam dua siklus. Siklus 1 terdiri dari 4 pertemuan dan siklus 2 terdiri dari 2 pertemuan. Teknik pengumpulan data dalam penelitian ini adalah observasi dan tes objektif. Instrumen yang digunakan adalah lembar observasi dan soal tes objektif. Validitas instrument diproses melalui expert judgement dari dosen ahli. Teknik analisis data yang digunakan adalah deskriptif kuantitatif dan deskriptif kualitatif. Indikator keberhasilan yang ditetapkan apabila apabila rata-rata kelas meningkat dari pratindakan, siklus I dan siklus II. Hasil penelitian menunjukkan bahwa hasil belajar Matematika siswa mengalami peningkatan. Hal tersebut ditunjukkan dengan peningkatan nilai rata-rata kelas yaitu pada saat pratindakan 6,8 meningkat menjadi 7,5 pada siklus I kemudian meningkat lagi pada siklus II menjadi 8,05. Selain itu dari data observasi diperoleh sebelum diberikan tindakan siswa terlihat kurang aktif dalam kegiatan pembelajaran, kegiatan pembelajaran lebih didominasi oleh guru. Setelah diberikan tindakan siswa terlihat aktif baik pada saat kegiatan tanya jawab maupun pada saat kegiatan kelompok.
\end{abstract}

Kata kunci: hasil belajar Matematika, Model Pembelajaran Kooperatif tipe TGT (Teams Games Tournaments). 


\section{PENDAHULUAN}

Rendahnya nilai hasil belajar siswa dari ulangan harian dengan materi faktor dan kelipatan tidak terlepas dari kurangnya variasi model pembelajaran yang digunakan oleh guru. "Model pembelajaran ialah pola yang digunakan sebagai pedoman dalam merencanakan pembelajaran di kelas"(Agus Suprijono, 2012: 46). Melihat jumlah siswa pada kelas V SDN Patrakomala yang berjumlah 18 orang hendaknya guru memilih model pembelajaran yang menekankan pada interaksi sosial antar siswa. Salah satu model pembelajaran yang berbasis sosial adalah model pembelajaran kooperatif.

Hal tersebut didukung oleh Johnson dan Johnson (Miftahul Huda, 2012: 265) yang menyatakan bahwa siswa yang bekerja secara kooperatif untuk mencapai tujuan bersama pada umumnya memiliki kemampuan akademik dan sosial yang memadai. Sejalan dengan pemikiran tersebut Nur Asma (2006: 26) menyatakan "Pembelajaran kooperatif juga dapat meningkatkan kerja keras siswa, lebih giat dan lebih termotivasi". Namun pada kenyataannya guru di kelas V SDN Patrakomala belum menerapkan model pembelajaran tersebut. Guru cenderung menggunakan model pembelajaran direct instruction di mana guru berperan aktif dalam pembelajaran sedangkan siswa hanya perlu mengingat apa yang telah disampaikan oleh guru. Dampak dari penggunaan model pembelajaran direct instruction yang diterapkan oleh guru dapat terlihat dari kurang termotivasinya beberapa siswa dalam mengikuti kegiatan pembelajaran. Slavin (Miftahul Huda, 2012: 68) menyatakan:

"jika model pembelajaran kooperatif tidak dirancang dengan baik maka pembelajaran kooperatif akan berdampak pada munculnya beberapa siswa yang tidak bertanggungjawab secara personal pada tugas kelompoknya, selain itu beberapa siswa yang dianggap tidak mampu cenderung diabaikan oleh anggota kelompok lainnya".
Untuk menghindari dampak tersebut penggunaan model pembelajaran kooperatif tipe TGT (Teams Games Tournaments) yang berisi game akademik mampu mendorong semua anggota kelompok untuk terlibat dalam pengerjaan tugas kelompoknya. "Dalam TGT setiap siswa ditempatkan dalam satu kelompok yang terdiri dari 3 orang berkemampuan rendah, sedang, dan tinggi" (Miftahul Huda,2012: 116). Melalui model pembelajaran tersebut siswa yang berkemampuan rendah dapat berperan aktif dalam pembelajaran melalui kelompoknya. Namun jika dilihat pada kenyataannya guru di kelas V SDN Patrakomala belum menggunakan model pembelajaran kooperatif.

Belajar merupakan kata yang tidak asing lagi dalam kehidupan manusia. Istilah belajar tidak terlepas dari proses pendidikan, bahkan masyarakat memahami belajar adalah sebagai suatu properti sekolah. Kegiatan belajar selalu dikaitkan dengan tugas-tugas sekolah. Travers dalam Agus Suprijono (2012: 2) menyatakan "belajar adalah proses menghasilkan penyesuaian tingkah laku". Berdasarkan pendapat tersebut belajar merupakan suatu proses yang di dalamnya terdapat berbagai macam aktivitas yang bertujuan untuk menghasilkan perubahan perilaku. Belajar terjadi dengan karena didorong kebutuhan dan tujuan yang ingin dicapai.

Rochmat Wahab dan Solehuddin (1999: 245) menyatakan "belajar merupakan aktivitas atau pengalaman yang menghasilkan perubahan pengetahuan, perilaku dan pribadi yang bersifat permanen". Belajar pada pendapat tersebut merupakan suatu bentuk pengalaman. Pengalaman pada dasarnya adalah hasil dari interaksi antara peserta didik dengan lingkungannya.

Hasil Belajar tidak terpisah dari proses belajar itu sendiri karena hasil belajar muncul karena adanya aktivitas belajar. Dengan kata lain hasil belajar adalah tujuan yang ingin dicapai dari kegiatan belajar. Agus Suprijono (2012: 5) 
menyatakan "hasil belajar adalah pola-pola perbuatan, nilai-nilai, pengertianpengertian, sikap-sikap, apresiasi dan ketrampilan". Soedijarto (Purwanto,2011: 46) menyatakan "hasil belajar adalah tingkat penguasaan yang dicapai oleh peserta didik dalam mengikuti proses belajar mengajar sesuai dengan tujuan pendidikan yang telah ditetapkan". menurut Permendiknas No 22 Tahun 2006 tentang Standar Isi menyebutkan bahwa mata pelajaran Matematika pada satuan pendidikan SD/MI meliputi aspek-aspek sebagai berikut:

a. Bilangan.

b. Geometri dan pengukuran.

c. Pengolahan data.

Kompetensi dalam bilangan ditekankan pada kemampuan melakukan dan menggunakan sifat operasi hitung bilangan dalam pemecahan masalah dan menaksir hasil operasi hitung. Geometri dan pengukuran ditekankan pada kemampuan mengidentifikasi pengelolaan data dan bangun ruang serta menentukan keliling, luas, volume, dalam pemecahan masalah. Pengelolaan data ditekankan pada kemampuan mengumpulkan, menyajikan dan membaca data.

\section{Definisi Model Pembelajaran}

Peningkatan kualitas pendidikan di sekolah dapat ditempuh melalui berbagai cara, antara lain peningkatan bekal awal siswa baru, peningkatan kompetensi guru, peningkatan isi kurikulum peningkatan kualitas pembelajaran, penilaian hasil belajara siswa, penyediaan bahan ajar yang memadai dan penyediaan sarana belajar.

Salah satu hal yang masih menjadi masalah besar pendidikan di indonesia terkait peningkatan kualitas pendidikan yaitu kurangnya kesadaran para pendidik untuk meningkatkan kualitas pembelajaran pada kelas yang diampunya. Dalam meningkatkan kualitas pembelajaran di

kelas guru harus mampu mendesain kegiatan pembelajaran yang dapat mengembangkan segala potensi siswa. Salah satu unsur penting dalam perencanaan pembelajaran adalah pemilihan model pembelajaran yang akan digunakan.

Joice (Trianto, 2010: 52) menyatakan bahwa "model pembelajaran adalah suatu perencanaan atau pola yang dapat kita gunakan untuk mendesain polapola mengajar secara tatap muka di dalam kelas atau mengatur tutorial, dan untuk menentukan material/ perangkat pembelajaran termasuk di dalamnya bukubuku, film-film, tipe-tipe, program media komputer, dan kurikulum.

Udin S Winataputra (2001: 3) menyatakan bahwa "model pembelajaran adalah kerangka konseptual yang melukiskan prosedur yang sistematis dalam mengorganisasikan pengalaman belajar untuk mencapai tujuan belajar tertentu, dan berfungsi sebagai pedoman bagi para perancang pembelajaran dan pengajar dalam merencanakan dan melaksanakan aktivitas pembelajaran".

$$
\text { Sejalan dengan pendapat }
$$

tersebut Arends (Agus Suprijono, 2012:46) menyatakan "model pembelajaran mengacu pada pendekatan yang akan digunakan, termasuk di dalamnya tujuantujuan pembelajaran, tahap-tahap dalam kegiatan pembelajaran, lingkungan pembelajaran, dan pengelolaan kelas".

Berdasarkan pendapat-pendapat tersebut dapat disimpulkan bahwa model pembelajaran adalah kerangka konseptual yang menggambarkan prosedur dalam mengorganisasikan pengalaman pembelajaran untuk mencapai tujuan pembelajaran. Model pembelajaran ini berfungsi sebagai pedoman bagi para pengajar dalam merancanakan dan melaksanakan kegiatan pembelajaran.

\section{Definisi Model Pembelajaran Kooperatif}

Agus Suprijono (2012: 30-31) menyatakan bahwa "pengetahuan adalah hasil konstruksi dari kegiatan atau tindakan seseorang sehingga pengetahuan seharusnya dikonstruksikan (dibangun) bukan dipersepsi secara langsung oleh indra". Pendapat tersebut menekankan 
bahwa kegiatan pembelajaran hendaknya lebih didominasi oleh aktivitas peserta didik dalam mengkonstruksi pengetahuannya bukan sebaliknya. Interaksi sosial antar peserta didik merupakan unsur yang terdapat dalam kegiatan pembelajaran tersebut sehingga dalam menentukan model pembelajaran yang akan digunakan guru dapat memilih beberapa model pembelajaran yang lebih menekankan pada aktivitas siswa salah satunya yaitu model pembelajaran kooperatif.

"Roger menyatakan Pembelajaran Kooperatif merupakan aktivitas pembelajaran kelompok yang diorganisir oleh satu prinsip bahwa pembelajaran harus didasarkan pada satu perubahan informasi secara sosial diantara kelompokkelompok pembelajar yang di dalamnya setiap pembelajar harus bertanggung jawab atas pembelajaranya sendiri dan didorong untuk meningkatkan pembelajaran anggota-anggota yang lain." (Miftahul Huda,2012: 29) Artz dan Newman

(Miftahul Huda,2012: 32)

mendefinisikan "pembelajaran kooperatif sebagai kelompok kecil pembelajar atau siswa yang berkerja sama dalam satu tim untuk mengatasi suatu masalah, menyelesaikan sebuah tugas, atau mencapai satu tujuan bersama".

\section{METODOLOGI}

Model penelitian yang digunakan dalam penelitian ini adalah penelitian Tindakan Kelas (PTK) yang bertujuan untuk meningkatkan hasil belajar matematika di kelas V SD Negeri Patrakomala, Bandung. Wina Sanjaya (2009: 26) menyatakan "Penelitian Tindakan Kelas (PTK) dapat diartikan sebagai proses pengkajian masalah pembelajaran di dalam kelas melalui refleksi diri dalam upaya untuk memecahkan masalah tersebut dengan cara melakukan berbagai tindakan yang terencana dalam situasi nyata serta menganalisis setiap pengaruh dari perlakuan tersebut".
Jenis penelitian tindakan kelas yang digunakan dalam penelitian ini adalah penelitian kolaboratif. Menurut Wina Sanjaya (2009: 59) dalam penelitian kolaboratif inisiatif untuk melaksanakan penelitian tidak dari guru tetapi dari pihak luar yang berkeinginan untuk memecahkan masalah pembelajaran. Penelitian ini akan menciptakan kolaborasi atau partisipasi antara peneliti dan guru kelas sehingga dapat membantu guru memperbaiki mutu pembelajaran di kelasnya. Peneliti terlibat langsung dalam proses penelitian sejak awal mulai dari tahap perencanaan sampai akhir dengan hasil penelitian berupa laporan. Selanjutnya peneliti memantau, mencacat, mengumpulkan data, lalu menganalisis data, serta berakhir dengan pelaporan hasil penelitian.

\section{HASIL DAN PEMBAHASAN}

Hasil belajar siswa pada kondisi awal mata pelajaran matematika masih rendah. Berdasarkan pengamatan yang peneliti lakukan hal tersebut disebabkan karena guru di SDN Patrakomala cenderung menggunakan model pembelajaran direct instruction di mana guru berperan aktif dalam pembelajaran sedangkan siswa hanya perlu mengingat apa yang telah disampaikan oleh guru.

Model pembelajaran yang digunakan oleh guru cenderung monoton dan membosankan, padahal Matematika merupakan pelajaran yang memerlukan cara berpikir ekstra keras sehingga guru hendaknya menggunakan model pembelajaran yang menyenangkan agar dapat menurunkan ketegangan berpikir anak. Data hasil test objektif siswa kelas V SDN Patrakomala pada kondisi awal sebelum penelitian menunjukkan nilai ratarata kelas 6,8.

Data nilai siswa pada kondisi awal sebelum penelitian tersebut jika divisualisasikan dalam bentuk diagram batang sebagai berikut 


\section{Nilai Matematika Siswa Kelas V Pra Tindakan}

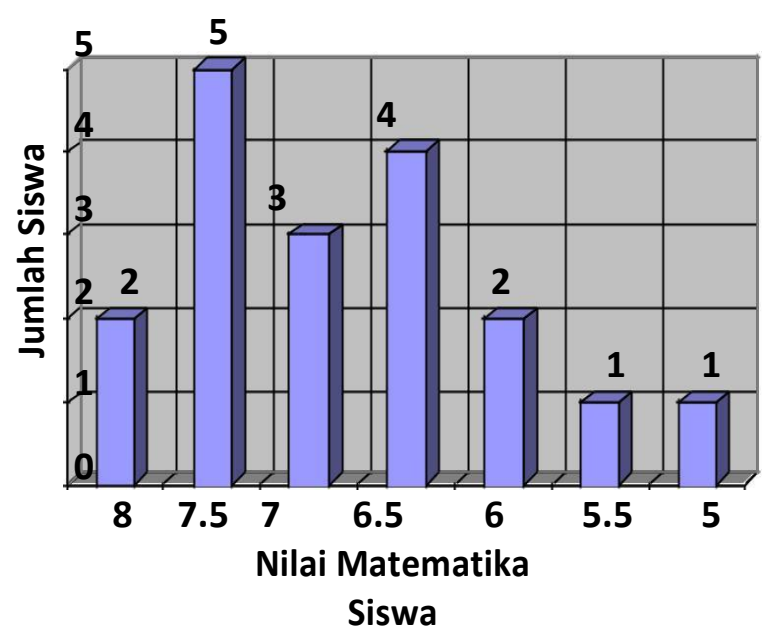

Diagram di atas menggambarkan nilai matematika yang diperoleh siswa pada saat pratindakan. Data tersebut diperoleh dari tes objektif yang dikerjakan siswa sebelum penerapan model pembelajaran kooperatif tipe TGT (Teams Games Tournaments). Hasil tes objektif tersebut menunjukkan nilai rata-rata kelas sebesar 6,8 .

Hasil Siklus I berupa rata-rata dari nilai evaluasi yang telah dilaksanakan pada tiap pertemuan pada siklus I. Hasil Siklus I jika digambarkan dalam bentuk tabel dan diagram sebagai berikut,

Tabel 4. Nilai Matematika siswa kelas V SDN Patrakomala pada Siklus I

\begin{tabular}{|c|c|c|c|}
\hline No & Nilai & $\begin{array}{c}\text { Jumlah } \\
\text { Siswa }\end{array}$ & Pencapaian \\
\hline 1 & 9 & 3 & Tuntas \\
\hline 2 & 8 & 5 & Tuntas \\
\hline 3 & 7 & 3 & Tuntas \\
\hline 4 & 6 & 7 & Belum Tuntas \\
\hline & 18 & & \\
\hline & & & \\
\hline
\end{tabular}

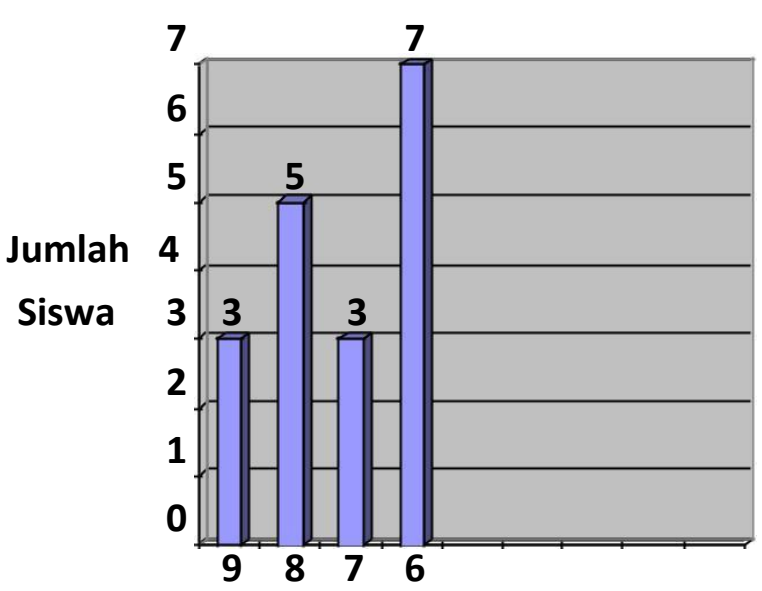

Nilai Matematika Siswa

Klasifikasi Nilai Matematika Kelas V SDN Patrakomala pada Siklus II

\begin{tabular}{|c|c|c|}
\hline No & Nilai & Jumlah Siswa \\
\hline 1 & 10 & $\overline{1}$ \\
\hline 2 & 9 & 6 \\
\hline 3 & 8 & 7 \\
\hline 4 & 7 & 1 \\
\hline 5 & 6 & 3 \\
\hline & lah & 18 \\
\hline
\end{tabular}

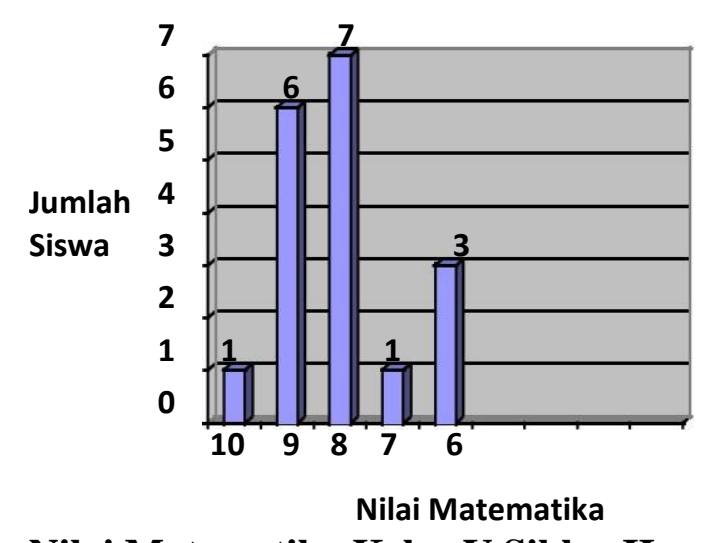

\section{Nilai Matematika Kelas V Siklus II}

Sehingga dapat diketahui nilai rerata siklus II adalah 8,05. Dari hasil tes pasca tindakan siklus II dapat diketahui nilai rerata tes pembelajaran menggunakan model pembelajaran kooperatif tipe TGT (Teams Games Tournaments) pascatindakan siklus II. Peningkatan perolehan rerata pasca tindakan siklus I 
dengan pascatindakan siklus II dapat dilihat pada diagram berikut:

\section{5}

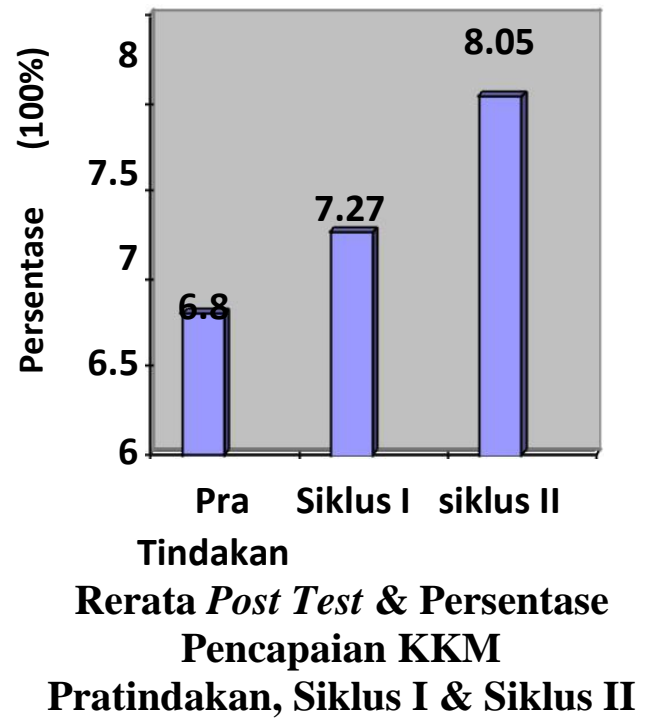

\section{PENUTUP}

Berdasarkan hasil penelitian dan pembahasan dapat disimpulkan bahwa penggunaan model pembelajaran kooperatif tipe TGT (Teams Games Tournaments) dapat meningkatkan hasil belajar matematika pokok bahasan operasi hitung bilangan bulat dan penggunaan faktor prima untuk menentukan KPK dan FPB siswa kelas V SD Negeri Patrakomala. Hal tersebut ditunjukkan dengan peningkatan nilai rata-rata kelas yaitu pada saat pratindakan 6,8 meningkat menjadi 7,5 pada siklus I kemudian meningkat lagi pada siklus II menjadi 8,05. Peningkatan hasil belajar siswa terjadi karena di dalam model pembelajaran kooperatif tipe TGT, siswa lebih termotivasi dan aktif dalam pembelajaran.

\section{DAFTAR PUSTAKA}

Agus Suprijono. (2012). Cooperative Learning Teori dan Aplikasi PAIKEM.

Yogyakarta: Pustaka Pelajar.
Azhar Arsyad. (2011). Media

Pembelajaran. Jakarta: PT Rajagrafindo Persada.

Hamzah B. Uno. (2008). Model Pembelajaran Menciptakan Proses Belajar Mengajar yang Kreatif dan Efektif. Jakarta: Bumi Aksara.

Herman Hudojo. (1992). Pendidikan Mtematika 2. Jakarta: Departemen Pendidikan dan Kebudayaan.

Heruman. (2008). Model Pembelajaran Matematika di Sekolah Dasar. Bandung: PT Remaja Rosdakarya.

Etin Solihatin \& Raharjo. (2009).

Cooperative Learning Analisis Model Pembelajaran IPS. Jakarta: PT.Bumi Aksara

Miftahul Huda. (2011). Cooperative Learning Metode,Teknik,Struktur dan Model Terapan. Yogyakarta: Pustaka Pelajar.

Nana Sudjana. (2005). Penilaian Hasil Proses Belajar Mengajar. Bandung: PT Remaja Rosdakarya.

Oemar Hamalik. (2001). Proses Belajar Mengajar. Jakarta: PT Bumi Akasara.

Purwanto. (2011). Evaluasi Hasil Belajar. Yogyakarta: Pustaka Pelajar.

Rochmat Wahab \& Solehuddin. (1999). Perkembangan dan Belajar Peserta Didik. Yogyakarta: Departemen Pendidikan dan Kebudayaan

Slameto. (2003). Belajar dan Faktorfaktor yang mempengaruhinya. Jakarta: PT Aneka Cipta.

Soewito dkk. (1992). Pendidikan Matematika I. Jakarta: 
Departemen Pendidikan dan Kebudayaan.

Sugiyono. (2010). Statistik untuk penelitian. Bandung: Alfabeta.

. (2011). Metode Penelitian

Pendidikan Pendekatan

Kuantitatif, Kualitatif, dan $R \& D$.

Bandung: Alfabeta.

Suharsimi Arikunto. (2006). Prosedur

Penelitian Suatu Pendekatan

Praktik.

Jakarta: PT Rineka Cipta.

Sumanto dkk. (2008). Gemar Matematika

5: untuk kelas V SD/MI. Jakarta:

Departemen Pendidikan Nasional.

Sunaryo. (2007). Matematika 5 : untuk

SD/MI kelas 5. Jakarta: Departemen

Pendidikan Nasional.

Trianto. (2010). Model Pembelajaran

Terpadu. Jakarta : PT.Bumi Aksara.

Tukiran Taniredja, Efi Miftah Faridli \& Sri

Harmianto. (2011). Model-model

Pembelajaran Inovatif. Bandung : Alfabeta

Udin S Winataputra. (2001). Model-Model

Pembelajaran Inovatif. Jakarta : PAU-

PPAI Universitas Terbuka.

Undang Undang no 20 tahun 2003 pasal 1

ayat 1

Wina Sanjaya. (2009). Penelitian

Tindakan Kelas. Jakarta: Kencana Prenada 